\title{
Assistência À Criança Hospitalizada e o Brincar no Hospital
}

\author{
Vieira, Ana Cristina de O. Almeida; Possari, Maria de Lourdes; Santos, Ana Regina \\ dos; Srougi, Miguel \\ Hopital das Clinicas FMUSP — anaavieira@usp.br
}

Introdução: a doença é uma situação de crise, altera a vida da criança e sua família, suscita ansiedade, angústia e conflitos. o Setor de Urologia Pediátrica atende a crianças e adolescentes acometidos por anomalias congênitas, câncer urológico, trauma entre outras patologias. As anomalias congênitas raras na população em geral, requerem tratamentos de alta complexidade por toda a vida, gerando expectativas idealizadas em torno do período de internação, da cirurgia e fantasias de cura, o que favorece o surgimento de conflitos e denunciam o sofrimento da criança e de seus pais. o processo de hospitalização infantil é marcante na vida de qualquer criança, uma vez que neste momento ela se percebe frágil e impossibilitada de realizar suas atividades, alterando a sua rotina diária como brincar e ir à escola. Quanto mais complexa a patologia da criança, maior a necessidade de assistência interdisciplinar, com olhares diversos que busquem alternativas para a melhoria da sua saúde e qualidade de vida. Assim, a brincadeira pode ser uma forma de enfrentamento desta situação de hospitalização, bem como uma forma de humanizar as relações no contexto da internação. a brinquedoteca favorece a amizade com outras crianças, auxilia na recuperação e ameniza os conflitos e sofrimentos da internação. Objetivos: Instrumentalizar a equipe de saúde para a utilização da brinquedoteca; permitir a expressão da vivência de internação por meio de atividades lúdicas. Método: Realizado revisão da literatura sobre o brincar e a importância da brinquedoteca em enfermarias pediátricas, instituiu-se um grupo de trabalho multidisciplinar para levantamento das necessidades e dificuldades na assistência à criança internada. Foram realizadas quatro reuniões em dias alternados e nos horários matutino e vespertino com representantes da equipe multidisciplinar e voluntários. As reuniões ocorreram no espaço da brinquedoteca, facilitando a compreensão e ambientação pela equipe. Neste contexto foram discutidas as seguintes questões: Qualquer procedimento ou intervenção cirúrgica anunciada à criança promove angustia, ansiedade e sofrimento pois sabe que tais procedimentos vão gerar dor física e desconforto; no relacionamento com a criança há que se considerar a perspectiva subjetiva, irracional, emocional e singular da criança; o ato de brincar é um sistema que integra a vida social das crianças e caracteriza-se por transmissão expressiva de forma compreensiva da realidade vivida através das brincadeiras realizadas. Resultado: Estabelecimento de horário fixo de funcionamento da brinquedoteca e orientação das mães que acompanham as crianças, a implantação de livro de controle para empréstimo de brinquedos e livros de história para crianças com locomoção limitada, criação de grupo de trabalho de artesanato com os pacientes, mães e ou acompanhantes.

Vieira, Ana Cristina de O. Almeida; Possari, Maria de Lourdes; Santos, Ana Regina dos; Srougi, Miguel. Assistência À Criança Hospitalizada e o Brincar no Hospital. In: Anais do Congresso Internacional de Humanidades \& Humanização em Saúde [= Blucher Medical Proceedings, num.2, vol.1]. São Paulo: Editora Blucher, 2014. ISSN 2357-7282

DOI 10.5151/medpro-cihhs-10467 